\title{
Effect of Participation in Development Initiatives on Competitive Advantages, Performance, and Sustainability of Micro-Enterprises in Malaysia
}

\author{
Abdullah Al Mamun', Rajennd Muniady ${ }^{2}$ and Noorul Azwin Binti Md Nasir ${ }^{3}$
}

\begin{abstract}
This study assessed the impact of micro-enterprise development initiatives (commonly provide access to financial services and micro-enterprise development training programs to low-income households) upon competitive advantages, performance, and sustainability of micro-enterprises owned and managed by selected low-income households in Peninsular Malaysia. Upon the adoption of cross-sectional design, data were randomly gathered from 300 micro-entrepreneurs residing in four states of Peninsular Malaysia selected from the eKasih database (national poverty data bank). The quantitative data had been collected by holding structured interview sessions with the participants from October until November 2017. The study outcomes revealed that the total amount of economic loan received, the total number of training hours and the number of center meetings/discussion attended exerted significantly positive effects upon competitive advantage, while marital status (control variable) was found to affect competitive advantage in a significantly positive manner. As for micro-enterprise performance, length of participation and number of center meetings/discussions attended as well as marital status as the control variable exhibited significantly positive effects. Meanwhile, the impact of participation duration, total amount of economic loan received, and number of center meetings/discussions attended upon micro-enterprise sustainability seemed to be inconclusive. Additionally, age of entrepreneurs and duration of enterprises establishment (micro-enterprise established) appeared to affect the aspect of sustainability. The findings appear to emphasize on the mixed effects of participation in development initiatives on competitive advantage, performance, and sustainability of micro-enterprises. Hence, this study recommends that the government of Malaysia formulate and adopt more specific strategies and policies in advocating development initiatives to ensure positive progression amongst micro-entrepreneurs and micro-enterprise owners.
\end{abstract}

KEY WORDS: $\quad$ Development Initiatives, Competitive Advantages, Performance, Sustainability.

JEL Classification: F61, M21.

'UCSI Graduate Business School, UCSI University, Cheras, Malaysia.

2Department of Business Studies, New Era University College, Malaysia

${ }^{3}$ Faculty of Entrepreneurship and Business, Universiti Malaysia Kelantan, Malaysia

\section{Introduction}

Poverty, vulnerability, and inequality issues have been widely debated in developing nations. Reportedly, developing nations experience high level of material deprivation and vast dispersion of in$\underline{\underline{0}}$ dividual well-being. With that being said, poverty

Correspondence concerning this article should be addressed to: Abdullah AI Mamun, UCSI Graduate Business School, UCSI University, Cheras, 56000 Kuala Lumpur, Malaysia.

E-mail:abdullaham@ucsiuniversity.edu.my alleviation and inequality reduction happen to be the top agenda amidst developing countries and the Millennium Development Goals (MDGs) of the United Nations. The notion of vulnerability (risk of experiencing poverty in the future) has been discussed widely, and followed by international economic shock, such as global economic crisis, which can escalate the poverty and hardcore poverty levels in a society (Heltberg et al., 2015). As for Malaysia, despite the reduction in poverty and hardcore pov- 
erty rates (Al-Mamun \& Mazumder, 2015; Ahmed et al., \& Mia, 2016), inequality in income distribution and socio-economic vulnerability to poverty have remained as threats among the low-income households in Malaysia, including other developed nations (Nair \& Sagaran, 2015).

In Malaysia, poverty denotes those who live below the poverty line income (PLI). The Malaysian government has defined poverty as lack of financial means to acquire the essential basic needs, including food and non-food components (Economic Planning Unit [EPU], 2002). In 2014, the PLI for households in Peninsular Malaysia, Sabah and Labuan, and Sarawak was RM930, RM1,170, and RM990, respectively (EPU, 2014). In fact, Malaysia displayed remarkable achievement in its poverty alleviation as households who lived below PLI had been successfully reduced from $50 \%$ to less than $1 \%$ in year 2014. The country also fruitfully achieved one of the MDGs in terms of extreme poverty and hunger eradication. Nonetheless, the issue of poverty has remained a major concern (Nair, 2010), mainly due to several stubborn pockets of poverty, inequality in income distribution, as well as new forms of poverty that require immediate attention (Nair \& Sagaran, 2015).

Micro-enterprise, as reflected in its term, refers to small-scale business activities operated by lowincome individuals. Micro-enterprises exist across the globe in the form of grocery stores, tailor shops, flower shops, recycling services, and food stalls, which allow low-income individuals to generate income and to be economically stable. At times, micro-entrepreneurs generate excess income that creates the possibility of home ownership, while labor-intense businesses offer employment opportunities. These suggest that micro-enterprise is a very good strategy for poverty alleviation and income generation (Banerjee, 1998; Deller \& McConnon, 2009; Abisuga-Oyekunle \& Fillis, 2016). As in the case of Malaysia, micro-enterprise is defined as a firm with less than RM300,000 sales turnover or less than 5 employees (Small and Medium Enterprise Corporation [SME Corp], 2017a). Micro-enterprises account for $76.47 \%$ of the SMEs and $75.34 \%$ of the overall establishments (SMEs and large firms combined) in Malaysia (SME Corp, 2017b). In total, the Malaysian SMEs contributed $36.6 \%$ to overall Gross Domestic Product (GDP) and accounted for $65.3 \%$ of total employment. This contribution from the economic stance of micro-enterprise is expected to have an impact on community and psycho-social level factors, such as self-confidence, empowerment, dignity, and family stability among micro-enterprise owners. Thus, micro-enterprise sustainability is vital to ensure sustainable socio-economic progress among the poor community worldwide.

The impact of development initiatives has been a popular research area among academic and nonacademic researchers. In fact, the positive effects of development initiatives have been questioned recently, as a number of studies have argued that the effects of development initiative program appear to be divergent from positive to nil impact and even negative (Angelucci et al., 2013; Ganle et al., 2015). Armendáriz et al. (2005) explained this variance by claiming that the impact of development initiatives differs from one context to another based on financial service providers, enterprise development, population density, group-cohesion, financial literacy, and attitudes to debt, among others. In Malaysia, microfinance, which refers to a development initiative, has a crucial role in the progress of socio-economy amongst those poor and low-income. Prior studies discovered the following in relation to microfinance programs: (a) increased microenterprise assets of the hardcore poor households (Al-Mamun et al., 2010), (b) increased employment-generating opportunities at community and household levels (Al-Mamun et al., 2011), (c) positive impact of total productive assets and number of gainfully employed (Al-Mamun et al., 2011), (d) significant relevance to performance of SMEs (Mahmood, \& Mohd Rosli, 2013), (e) increased entrepreneur income that positively affects business and fulfills the basic needs of entrepreneurs (Hassan, \& Ibrahim, 2015), (f) positive impact on household income (Samer et al., 2015), as well as (g) positive effects upon borrowers' household income, personal assets acquisition, and empowerment of women in household decision-making (Al-Shami et al., 2017).

The major consideration given to micro-enterprises in economic development and employment creation, is similar to the provision of micro-credit 
to the poor for investment in income-generating activities, which share the same objective - eradication of poverty through competitive advantage, performance, and sustainability creation. Thus, it is essential to have a clear picture regarding the provision of micro-credit to micro-entrepreneurs, particularly when micro-enterprises are connected to each another. As the impact of microfinance may differ from one context to another, this study investigated the effect of participation in development initiatives on competitive advantages, performance, and sustainability of micro-enterprises in Malaysia.

The presentation of this paper is further divided into 4 Sections. After the introduction, Section 2 presents the Literature Reviews; Section 3 about Research Methodology; Section 4 presents the summary of findings and lastly Section 5 concludes the results. Prior to Section 2, a brief explanation on the study context is explained.

\subsection{Study Context: Development Organiza- tions in Malaysia}

The significant roles of development organizations in the effort of reducing poverty, inequality, and vulnerability cannot be dismissed in terms of their micro-credit and training programs. The major names of microfinance institutions (MFIs) established in Malaysia are: Amanah Ikthiar Malaysia (AIM), National Entrepreneurs Economic Group Fund (TEKUN), Federal Land Consolidation and Rehabilitation Authority (FELCRA), Department of Orang Asli Development (JAKOA), Rubber Industry Smallholders Development Authority (RISDA), Federal Agricultural Marketing Authority (FAMA), Community Development Department (KEMAS), Malaysia Fisheries Development Board (LKIM), and The Council of Trust for the Bumiputera (MARA). AIM practices group-based lending of the Grameen Banks, whereby their loans range between RM2,000 and RM20,000 based on various financing schemes, as well as weekly repayment that ranges from 12 until 150 weeks. As the biggest MFI in Malaysia, AIM has 342,887 clients throughout its 136 branches nationwide with total loan amounting to RM1.99 billion, in which the total loan given out until 2017 exceeded RM18 billion slightly (AIM, 2017). On the other hand, TEKUN reaches the poor through their varied six financing schemes and three training programs. Their loan amount ranges between RM1,000 and RM100,000 with weekly or monthly repayment starting from 6 months until 5 years. At the same time, TEKUN offers four types of training programs, namely: Basic Entrepreneurship Seminar, Advance Entrepreneurship Course, Pre-Participation Seminar, and Public Entrepreneurship Seminar.

\section{Literature Review}

A whopping number of 836 million people had been reported to be living in extreme poverty condition (United Nations Development Programs [UNDP], 2017), where one in every five people in developing regions survive on less than US\$1.25 per day. Although a slump was recorded in the numbers from 1.9 billion people living in extreme poverty in 1990, the figure is still staggering considering the growth of economy in other parts of the globe. As a major player in the development initiatives, the UNDP has gone further than poverty alleviation, where other goals, such as protecting the planet; ensuring that all people enjoy peace, justice, and prosperity; addressing climate change and economic inequality; sparking innovation; and highlighting sustainable consumption, are among others that have been upheld and looked into. All these goals are interconnected and so far UNDP has managed to bring down poverty rate from 1.9 billion to 836 million people; 50\% reduction in preventable child deaths; $45 \%$ reduction in maternal mortality; and increment in school enrollment amidst developing nations from $52 \%$ to $78 \%$ (1990-2012). However, the focus of many other development initiatives is particularly regarding poverty alleviation as poverty is the root of other socio-economic issues.

The literature has identified employment as the basic answer to move out of poverty (Bikbaeva \& Gaibnazarova, 2009), where increment in several aspects, such as self-employment, productivity of the self-employed, wages, and labor productivity has helped the poor to escape poverty. Economic growth, productive employment, and poverty are interconnected, whereby economic growth increases productive employment (reduces poverty), while productive employment increases 
economic growth (again, reduces poverty). In order to achieve productive employment, microfinance appears to be an essential factor due to its positive effect on macroeconomics and those with entrepreneurial potential to start up or to expand their businesses (Bikbaeva \& Gaibnazarova, 2009). In ensuring that the poor could earn sufficiently, the micro-credit approach facilitates in providing financial resources to the needy. Since the introduction of MFIs during the 1970s, following the Grameen Bank model in Bangladesh, the reach of MFIs has grown manifolds. From 2002 until 2011, the number of active borrowers in developing nations increased by $400 \%$ and the gross loan portfolio escalated by more than $1700 \%$ (Donou-Adonsou \& Sylwester, 2016).

The MFIs also have a significant function to eradicate poverty in Malaysia. Apart from addressing poverty, programs established by MFIs have been empirically proven to not only improve rural enterprise, but also to increase skills, confidence, and social standing among rural women (Chan \& Abdul Ghani, 2011; Banerjee et al., 2015; Chan. \& Ghani, 2011; Clark \& Douglas, 2014; Montgomery \& Weiss, 2011). Apart from improvements at individual level, MFIs are found to affect entrepreneurs positively, increase their earnings, and fulfil their basic needs (Hassan \& Ibrahim, 2015). Another study that evaluated the quality of life among MFIs participants by comparing between old and new participants discovered that old participants lived in better and bigger houses, used permanent housing materials, used environmentally safe cooking fuel, enjoyed healthy lavatory facilities, as well as owned refrigerators, washing machines, and televisions more than the new participants (Al-Mamun et al., 2010).

\subsection{Development Initiatives and Competitive Advantages}

Competitive advantage refers to the ability of an organization to perform its activities differently that other organizations cannot imitate (Kotler, 2000). Porter (1996) claimed that competitive advantage is the ability of an organization to constantly earn above the average of the industry, while Barney (1991) defined competitive advantage as the implementation of strategic value-creation that is not implemented by current or potential competitors. As suggested by Porter (1996), competitive advantage can be achieved via three viable strategies: focus, differentiation, and cost leadership. This means; when customers value an organization's product and services more than its competitors, the organization is said to have gained competitive advantage. Thus, competitive advantage ensures that an organization is different and earns more, as compared to its contenders, which can be translated as better economic performance. Ma (2000) explained that it is highly likely for an organization to offer added value product and/or services for customers to exert better performance. A recent empirical study conducted by Kuo et al. (2017) revealed that competitive advantage is positively related to organizational performance. Due to the significance of competitive advantage towards performance of enterprises, capability building has been regarded as a compliment to microcredit, which is predicted to increase the level of competitive advantage of an enterprise, while a loan without capability building might cause mission drift (Molnár, 2017) and retain the poor stuck at bottom. A recent study by Al-Mamun et al. (2018) proved that social capital and entrepreneurial competencies displayed significantly positive effects upon competitive advantage among women-owned and managed micro-enterprises. Therefore, participation in development programs is expected to enhance competitive advantage of participants, thus the following hypothesis:

Hypothesis 1: Participation in Development Programs leads to improvement in Competitive Advantages for Micro-Enterprises owned and managed by low-income households in Peninsular Malaysia.

\subsection{Development Initiatives and Micro-En- terprise Performance}

Poor and low-income households weigh in entrepreneurship as the only way to escape the poverty trap and climb-up the social ladder. 
This view is promoted with the assumption that entrepreneurs are wealthy and possess better consumption capability. Past studies revealed that entrepreneurship reduced inequality in income distribution (Halvarsson et al., 2018), and increased household wealth and income (Gentry \& Hubbard, 2004). Hence, entrepreneurship is regarded as a viable livelihood strategy as it complements salaried employment, apart from raising income and labor utilization (Fields, 2012). This is aligned with study from Mahmood \& Rosli (2013) that microfinance programs are significantly relevant to the performance of SMEs. With the objective of increasing performance, development programs are tailored to provide loans and training with their very own proponents and empirical findings. Some findings suggest that development initiatives, in general, have a positive impact on enterprise performance (Atmadja et al., 2016; Akingunola et al., 2018; Gampala, 2018). Therefore, based on the existing evidences, the following hypothesis is proposed:

Hypothesis 2: Participation in Development Programs leads to improvement in Performance of Micro-Enterprises owned and managed by lowincome households in Peninsular Malaysia.

\subsection{Development Initiatives and Micro-En- terprise Sustainability}

The notion of sustainability has been debated in recent years following the changes in economic, environmental, and social dynamics of the modern world. Recent decades have witnessed more economic turbulences, environmental catastrophes, and social economic issues. Following that, enterprises seem to face more obstacles to sustain in the current economic environment, which demands entrepreneurs to pay attention to sustainability, for it is the only future success strategy (Danciu, 2013). Sustainability can be categorized into three main aspects of society, environment, and economy (Elliott, 2013), which have to be addressed together, and not independently, so as to make profit and contribute to the economic system, while maintaining social peace and preserving environmental system (Danciu, 2013). Since the main concern of the sustainability concept is sustainable business survival, it is expected to affect business performance in a positive manner. Moreover, the direction of development initiatives is channeled towards sustained performance, in which attention is shed on sustainability. This study argues that loan and training programs provided by development organizations do affect enterprise sustainability. In fact, some studies found that development programs directed to SMEs did exhibit a positive effect on their sustainability (Ferdousi, 2015; Hassan \& Ibrahim, 2015; Mustapa et al., 2018). Thus, the following hypothesis is proposed:

Hypothesis 3: Participation in Development Programs leads to improvement in Sustainability for Micro-Enterprises owned and managed by lowincome households in Peninsular Malaysia.

\section{Research Methodology}

This study adopted the cross-sectional design and gathered quantitative data via structured interviews to investigate the impact of micro-enterprise development initiatives (commonly provide access to financial services and micro-enterprise development training programs to low-income households) on competitive advantages, performance, and sustainability of microenterprises owned and managed by low-income households in Peninsular Malaysia. The selected participants were those interested in socio-economic development of low-income and poor households through provision of working capital and enterprise development training programs. All information pertaining to the development organizations and participants was retrieved from the eKasih National Poverty Data Bank. As a result, a list of 400 randomly selected low-income and poor households had been gathered from Kelantan, Terengganu, Kedah, and Perlis. Prior to data collection, a team of researchers contacted the selected households to explain the survey objective and to set interview appointments upon agreement. The entire data collection took two months; from October until November 2017. A total of 300 participants allowed the research team to visit their residences for interview purpose. All association hypnotized and tested presented in Figure 1. 


\subsection{Sample Size}

The sample size was calculated by using G-Power version 3.1. Based on the power of 0.95 (should exceed 0.80 for social and behavioral science research) with an effect size of 0.15 , this study required a sample size of 199 to test the model that had fifteen predictors. In order to avoid any possible limitations arising from a small sample size, a total of 300 low-income and poor households were selected from those living in Kelantan, Terengganu, Kedah, and Perlis.

\subsection{Research Instrument}

The questionnaire was designed by using simple and unbiased terms to ensure that the participants easily understood the questions and provided answers based on their own perceptions. The questions had been adapted from prior studies with minor modifications. The items for Enterprise Performance were adopted from Muniady et al. (2015). Next, in the attempt to assess Sustainability, the questions were adopted from Mann and Gazzarin (2004), as well as Ocampo et al. (2015). Lastly, in order to measure Competitive Advantages, the related items were adopted from Norshafizah (2012).

\subsection{Participation in Development Initiatives}

The participation variables included in this study are as follows: (a) Number of years (the number of years involved as a development organization participant); (b) Total amount of Economic Loan Received (the total amount of loan received for income-generating activities); (c) Total number of training hours (the total number of training hours provided by development organization); (d) Total number of center meetings/ discussions (the total number of center meetings/discussions attended by participants organized by development organizations).

\subsection{Control Variables}

Other variables that had been predicted to affect micro-enterprise performance, competitive advantage, and sustainability in varied ways are listed as follows: Gender, Marital Status, Age, Education, Sources of Income, Experience, Firm Established, Full-Time Employees, Part-Time Employees, and Working Hours. Males who lead micro-enterprises, in comparison to females, had been assumed to generate higher income and assets; while married household heads, when compared to divorced, widowed, and separated household, might face more challenges in attaining certain economic level. The assumption on age and experience is that, one who is elder has more experiences that may bring a positive difference. This similar view is applied on the education variable, where the higher the level of education, they are better equipped with knowledge and skills. Furthermore, having more employees both full-time and part-time had been expected to affect the micro-enterprises positively. The length of firm establishment and working hours were translated to commitment and effort invested to the survival of the firm. Lastly, sources of income were expected to enhance the performance of micro-enterprise. Past studies discovered that age, gender, marital status, education (Islam et al., 2016), number of employees (Adekunle, 2011), and working hours (Berrone et al., 2014) did affect micro-enterprise performance. Additionally, experience, as prior entrepreneurial experiences (Atmadja et al., 2016), and Firm Establishment (firm age) (Adekunle, 2011) were found to affect micro-enterprise performance. Sources of Income was integrated as a control variable in a study carried out by Al Mamun and Mazumder (2015) and had been proven to affect household income, which is an expected outcome from development organization participation. In respect of gender, male and female were coded as ' 1 ' and ' 0 ', respectively; gender had been expected to influence micro-enterprise competitive advantage, performance, and sustainability. As for marital status, the status married was coded as ' 1 ' while single, separated, divorced, and widowed were coded as ' 0 '. In short, married households were expected to have better chances

\section{Summary of Findings}

\subsection{Demographic Characteristics}

Data were gathered from 300 low-income households living in Kelantan, Terengganu, Kedah, and Perlis. Most of the participants (53.7\%) were males. Next, a total of $111(37 \%)$ of the participants were in the age range of 31 until 40 years old, followed by 85 (28.3\%) of them in the age range between 41 and 50 years old, while $66(22 \%)$ participants were from 51 until 60 years old. However, only 10 (3.3\%) participants were in 


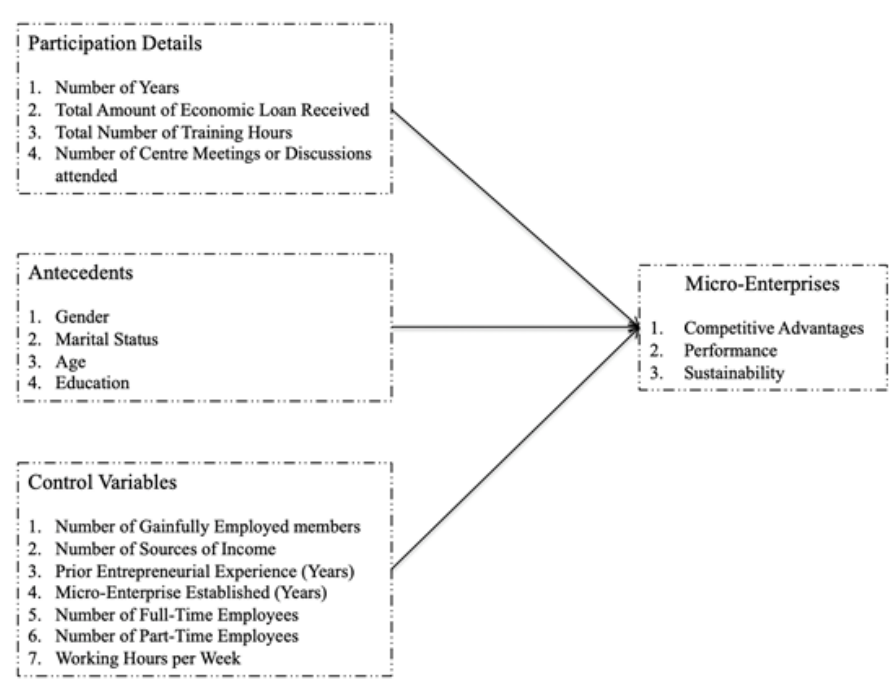

Figure 1. Research model.

Table 1. Participation Details

\begin{tabular}{lcccc}
\hline & Minimum & Maximum & Mean & Std. Dev. \\
\hline Number of Years & 2.00 & 16.00 & 9.3000 & 3.62221 \\
Total amount of economic loan received & 6000 & 130000 & 41503.67 & 26709.88 \\
Total number of training hours & 1 & 130 & 40.48 & 26.759 \\
Number of Centre Meetings or Discussions attended & 0 & 4 & 1.39 & 0.977 \\
\hline
\end{tabular}

Table 2. Control Variables

\begin{tabular}{lcccc}
\hline & Minimum & Maximum & Mean & Std. Dev. \\
\hline Number of Gainfully Employed members & 1 & 4 & 1.88 & .574 \\
Number of Sources of Income & 1 & 3 & 1.31 & .517 \\
Prior Entrepreneurial Experience (Years) & 0 & 20 & 3.01 & 3.974 \\
Micro-Enterprise Established (Years) & 2 & 6 & 3.49 & 1.111 \\
Number of Full-Time Employees & 0 & 3 & .52 & .667 \\
Number of Part-Time Employees & 0 & 2 & .29 & .476 \\
Working Hours per Week & 20 & 90 & 54.35 & 18.290 \\
\hline
\end{tabular}


the range of 20 to 30 years old. In terms of marital status, $243(81.0 \%)$ of the participants were married, while $7 \%$ and $1.3 \%$ were widowed and separated, respectively. In respect of education background, most of the participants $(31.7 \%)$ received primary school education, while $81(27 \%)$ of them completed their secondary school education. Surprisingly, 2 (0.7\%) of them were Master's degree holders and $17 \%$ had never attended school. In addition, 200 (66.7\%) households had two gainfully employed members, while 69 (23\%) of them had only one employed member, but only one $(0.3 \%)$ household had four gainfully employed members. The remaining $30(10 \%)$ declared three employed members. Last but not least, most of the participants (72\%) relied on one source of household income. A total of 76 (25.3\%) households depended on two sources of income, while the remaining eight households (2.7\%) had three sources of income.

\subsection{Participation in Developing Programs}

Table 1 shows that the mean value for participation years in development programs had been 9.3 years with a standard deviation of 3.62 years. The mean value for the total amount of economic loan received was RM41,503.67 with a standard deviation of RM26,709.88, while the mean for the total number of training hours was 40.48 hours with a standard deviation of 26.76 hours. Finally, the mean value for the number of center meetings/discussions attended in the last 12 months was 1.39 with a standard deviation of 0.977 .

\subsection{Control Variables}

Table 2 presents the description of control variables used in this study. Each household had at least one employed member and a maximum of four employed members with a mean value of 1.88 . They had one to three sources of income with a mean value of 1.31 . Those micro-entrepreneurs began afresh without any prior entrepreneurial experience and some had 20 years of experience. Their present micro-enterprises had been established between 2 and 6 years ago with a mean value of 3.49. Some micro-enterprises had no full-time or part-time employees, while some had a maximum of 3 full-time and 2 part-time employees with standard deviation values of 0.52 and 0.29 , respectively. It was discovered that micro-enterprise owners worked between 20 and 90 hours per week in their es- tablishments.

\subsection{Outcome Variables}

Table 3 displays the outcomes of descriptive and reliability analyses for the dependent variables: competitive advantage, performance, and sustainability of micro-enterprise. It was noted that all three variables had Cronbach's alpha values exceeding 0.7 , thus confirming their reliability. The aspects of competitive advantage, performance, and sustainability exhibited mean values of 4.8193, 0.5194, and 4.1856, respectively.

\subsection{Impact on Competitive Advantage}

A partial correlation was performed to determine the correlations between competitive advantage, number of years, total amount of economic loan received, total training hours, and number of center meetings/discussions attended after controlling the impacts of gender, marital status, age, education, gainfully employed members, sources of income, prior entrepreneurial experience, micro-enterprise establishment, full-time and part-time employees, and working hours per week (see Table 4). The results revealed a negative relationship between competitive advantage and participation years although it was statistically insignificant. The findings also reported a significantly positive correlation between total amount of economic loan received, total number of training hours, total number of center meetings/discussions attended, and competitive advantage.

The $r^{2}$ value was 0.225 , which indicated that $22.5 \%$ of the variation in 'competitive advantage' can be explained by years of participation, total amount of economic loan received, total number of training hours, total number of center meetings/discussions attended, gender, marital status, age, education, sources of income, experience, firm establishment, full-time and part-time employees, as well as total number of working hours. The Durbin-Watson statistics of 1.062 was below 2 , thus signifying the absence of autocorrelation. The VIF values for all variables were below 3 , thus indicating the absence of multicollinearity issue. Since the $\mathrm{p}$-value from the ANOVA analysis had been lower than 0.001 , at least one variable was used to model 'competitive advantage'.

Given that the Kolmogorov-Smirnov test of normality for the residuals gained a $p$-value of 0.001 , which is less than 0.05 , it failed to meet the assumption of normal- 
Table 3. Outcome Variables

\begin{tabular}{lcccccc}
\hline & N. Items & CA & Minimum & Maximum & Mean & Std. Dev. \\
\hline Competitive Advantages & 5 & 0.753 & 3.00 & 7.00 & 4.8193 & .73062 \\
& & & & & & \\
Micro-Enterprise Performance & 6 & 0.810 & 2.83 & 5.00 & 3.5194 & .51446 \\
Micro-Enterprise Sustainability & 6 & 0.802 & 3.00 & 6.00 & 4.1856 & .81514 \\
\hline
\end{tabular}

Note: Cronbach's Alpha (CA)

Table 4. Partial Correlation

\begin{tabular}{|c|c|c|c|c|c|c|}
\hline Variables & & ComA & Year & Loan & Training & MD \\
\hline \multirow[t]{2}{*}{ Competitive Advantages } & Correlation & 1.000 & & & & \\
\hline & Sig. (1-tailed) & . & & & & \\
\hline \multirow[t]{2}{*}{ Number of years } & Correlation & -.039 & 1.000 & & & \\
\hline & Sig. (1-tailed) & .257 & . & & & \\
\hline \multirow[t]{2}{*}{ Total amount of economic loan received } & Correlation & .137 & .238 & 1.000 & & \\
\hline & Sig. (1-tailed) & .010 & .000 & . & & \\
\hline \multirow[t]{2}{*}{ Total number of training hours } & Correlation & .238 & .070 & .057 & 1.000 & \\
\hline & Sig. (1-tailed) & .000 & .118 & .167 & . & \\
\hline \multirow{2}{*}{$\begin{array}{l}\text { Number of Centre Meetings or Discussions } \\
\text { attended }\end{array}$} & Correlation & .188 & -.148 & -.112 & .266 & 1.000 \\
\hline & Sig. (1-tailed) & .001 & .006 & .029 & .000 & . \\
\hline
\end{tabular}

Note:

(a) ComA - Competitive Advantages; Years - Number of years; Loan - Total amount of economic loan received; Training - Total number of training hours; MD - Number of Centre Meetings or Discussions attended

(b) Control variables - gender, marital status, age, education, gainfully employed members, sources of income, prior entrepreneurial experience, micro-enterprise established, number of full-time employees, number of part-time employees, working hours per week.

ity. The non-standardized residual stem-and-leaf plot revealed the outliers based on the non-standardized residual values. After removing a total of 47 outliers, the p-value for Kolmogorov-Smirnov test of normality improved to 0.20 , which exceeded 0.05 , thus satisfying the assumption of normality. This study presents the analysis using data gathered from 253 participants, where the standardized beta and the p-values are tabulated in Table 5.

The outcomes revealed that the total amount of economic loan received, the total number of training hours, and the number of center meetings/discussions attended displayed significantly (at 5\% level of significance, $\mathrm{N}=300$ and $\mathrm{N}=253$ ) positive effects upon competitive advantages for micro-enterprises owned and managed by low-income households in Peninsular Malaysia (Hypothesis 1). Nonetheless, length of participation exhibited an insignificant negative effect upon both groups. As for the effect of control variables, the results revealed significantly positive impact of marital status on competitive advantages for micro-enterprises owned and managed by low-income households. Nevertheless, the effects of other control variables were mostly inconclusive (the direction of the link and the level of 
significance) upon the two groups ( $\mathrm{N}=300$ and $\mathrm{N}=253)$.

\subsection{Impact on Micro-Enterprise Performance}

A partial correlation was performed to determine the correlations between micro-enterprise performance, number of years, total amount of economic loan received, total number of training hours, and total number of center meetings/discussions attended after controlling the effects of gender, marital status, age, education, gainfully employed members, sources of income, prior entrepreneurial experience, micro-enterprise establishment, full-time and parttime employees, and working hours per week (see Table 6). The outcomes revealed a significantly positive relationship between participation years, number of center meetings/discussions attended, and microenterprise performance. The results signified a significantly negative link between total number of training hours and micro-enterprise performance. Besides, an insignificantly positive correlation was established between total amount of economic loan received and micro-enterprise performance.

The $r^{2}$ value was 0.256 , which pointed out that $25.6 \%$ of the variation in 'micro-enterprise performance' can be explained by years of participation, total amount of economic loan received, total number of training hours, total number of center meetings/ discussions attended, gender, marital status, age, education, sources of income, experience, firm establishment, full-time and part-time employees, and the total number of working hours. The Durbin-Watson statistics of 2.083 was slightly higher than 2 , thus indicating the absence of autocorrelation. The VIF values for all variables were below 3 , hence relating the absence of multicollinearity issue. Since the $p$-value of the ANOVA analysis was less than 0.001 , at least one variable was used to model 'micro-enterprise performance'.

Given that the Kolmogorov-Smirnov test of normality for the residuals gained a $p$-value of 0.046 , which was less than 0.05 , it failed in meeting the assumption of normality. The non-standardized residual stem-and-leaf plot displayed that the outliers had been based on non-standardized residual values. After discarding 31 outliers, the $p$-value for the KolmogorovSmirnov test of normality exceeded 0.05 , thus satisfying the assumption of normality. This study presents the analysis using data gathered from 269 participants, where the standardized beta and the p-values are depicted in Table 7.

The outcomes revealed that the duration of participation (in years) exhibited a positive effect upon micro-enterprise performance. Nevertheless, the effects of total amount of economic loan received and total number of training hours had been inconclusive (direction of the association and level of significance) for both groups $(\mathrm{N}=300$ and $\mathrm{N}=253)$. The results failed to provide clear evidence regarding the impact of development programs participation on the performance of micro-enterprises owned and managed by low-income households in Peninsular Malaysia (Hypothesis 2). As for the effects of the control variables, the outcomes showed significantly negative impact of gender (coded ' 1 ' for Male, while ' 0 ' for Female) on micro-enterprise performance, thus signifying that micro-enterprises owned and managed by women performed significantly better than that of their male counterpart. The findings also showcased a significantly positive effect of marital status on micro-enterprise performance, which indicated that the income from married entrepreneurs had been significantly higher than that of other marital status. The effects of other control variables, however, were mostly inconclusive (direction of the association and level of significance) across the two groups ( $\mathrm{N}=300$ and $\mathrm{N}=269)$.

\subsection{Impact on Micro-Enterprise Sustainability}

A partial correlation was performed to assess the correlations between micro-enterprise sustainability, total number of years, total amount of economic loan received, total number of training hours, and total number of center meetings/discussions attended after controlling the impacts of gender, marital status, age, education, gainfully employed members, sources of income, prior entrepreneurial experience, microenterprise establishment, full-time and part-time employees, and working hours per week (see Table 8 ). The results revealed a significantly negative link between total number of center meetings/discussions attended and micro-enterprise sustainability. The results also displayed insignificantly negative relationships between total participation years, total amount of economic loan received, total number of training hours, and micro-enterprise sustainability.

The $r^{2}$ value was 0.235 , which indicated that $23.5 \%$ of the variation in 'micro-enterprise sustainability' 
Table 5. Regression Coefficients

\begin{tabular}{|c|c|c|c|c|c|c|c|}
\hline & \multirow[t]{2}{*}{ Unst. Beta } & \multirow{2}{*}{$\begin{array}{c}\mathrm{N}=\mathbf{3 0 0} \\
\text { Std. Error }\end{array}$} & \multirow[t]{2}{*}{ Stan. Beta } & \multirow[t]{2}{*}{ Sig. } & \multirow[t]{2}{*}{ VIF } & \multicolumn{2}{|c|}{$N=253$} \\
\hline & & & & & & Stan. Beta & Sig. \\
\hline (Constant) & 4.603 & .301 & & .000 & & & .000 \\
\hline Years & -.015 & .013 & -.075 & .244 & 1.506 & .067 & .201 \\
\hline Loan & $5.213 \mathrm{E}-006$ & .000 & .191 & .007 & 1.819 & .162 & .003 \\
\hline Training & .005 & .002 & .191 & .001 & 1.208 & .295 & .000 \\
\hline MD & .107 & .045 & .144 & .017 & 1.317 & .080 & .101 \\
\hline Gender & -.133 & .098 & -.091 & .179 & 1.656 & -.341 & .000 \\
\hline Marital Status & .156 & .044 & .257 & .000 & 1.898 & .136 & .023 \\
\hline Age & -.055 & .051 & -.079 & .280 & 1.936 & .188 & .003 \\
\hline Education & .009 & .039 & .015 & .812 & 1.526 & .042 & .413 \\
\hline GEM & .148 & .093 & .117 & .113 & 1.967 & .290 & .000 \\
\hline Sources of Income & .096 & .099 & .068 & .333 & 1.810 & -.148 & .009 \\
\hline Experience & -.032 & .011 & -.173 & .004 & 1.318 & -.211 & .000 \\
\hline Established & .024 & .050 & .037 & .633 & 2.150 & -.137 & .027 \\
\hline Full-Time Employees & .039 & .071 & .036 & .578 & 1.531 & .142 & .006 \\
\hline Part-Time Employees & -.018 & .092 & -.012 & .848 & 1.318 & -.167 & .001 \\
\hline Working Hours & -.009 & .003 & -.220 & .001 & 1.469 & -.390 & .000 \\
\hline
\end{tabular}

Note: (Dependent variable) Competitive Advantages

(Independent variables) Years - Number of years; Loan - Total amount of economic loan received; Training - Total number of training hours; MD - Number of Centre Meetings or Discussions attended

(Control Variables) Gender, Marital Status, Age, Education, GEM - Gainfully Employed Members, Sources of Income, Experience - Prior Entrepreneurial Experience (Years), Established - Micro-Enterprise Established (Years), Number of FullTime Employees, Number of Part-Time Employees, Working Hours Per Week

Table 6. Partial Correlation

\begin{tabular}{|c|c|c|c|c|c|c|}
\hline Variables & & MEP & Year & Loan & Training & MD \\
\hline \multirow[t]{2}{*}{ Micro-Enterprise Performance } & Correlation & 1.000 & & & & \\
\hline & Sig. (1-tailed) & . & & & & \\
\hline \multirow[t]{2}{*}{ Number of years } & Correlation & .238 & 1.000 & & & \\
\hline & Sig. (1-tailed) & .000 & . & & & \\
\hline \multirow[t]{2}{*}{ Total amount of economic loan received } & Correlation & .070 & .057 & 1.000 & & \\
\hline & Sig. (1-tailed) & .118 & .167 & . & & \\
\hline \multirow[t]{2}{*}{ Total number of training hours } & Correlation & -.148 & -.112 & .266 & 1.000 & \\
\hline & Sig. (1-tailed) & .006 & .029 & .000 & . & \\
\hline \multirow[t]{2}{*}{ Number of Centre Meetings or Discussions attended } & Correlation & .126 & .035 & -.140 & -.274 & 1.000 \\
\hline & Sig. (1-tailed) & .016 & .279 & .009 & .000 & . \\
\hline
\end{tabular}

\section{Note:}

(a) MEP - Micro-Enterprise Performance; Years - Number of years; Loan - Total amount of economic loan received; Training - Total number of training hours; MD - Number of Centre Meetings or Discussions attended

(b) Control variables - gender, marital status, age, education, gainfully employed members, sources of income, prior entrepreneurial experience, micro-enterprise established, number of full-time employees, number of part-time employees, working hours per week. 
can be explained by participation years, total amount of economic loan received, total number of training hours, total number of center meetings/discussions attended, gender, marital status, age, education, sources of income, experience, firm establishment, full-time and part-time employees, and total number of working hours. The Durbin-Watson statistics of 1.477 was below 2, thus signifying the absence of autocorrelation. The VIF values for all variables were below 3, hence pointing out the absence of multicollinearity issue. Since the $p$-value from the ANOVA analysis was lower than 0.001 , at least one variable was used to model 'micro-enterprise sustainability'. Given that the Kolmogorov-Smirnov test of normality for the residuals gained a $p$-value of 0.000 , which was less than 0.05 , it failed to achieve the assumption of normality. The non-standardized residual stem-and-leaf plot showed that the outliers had been based on non-stan- dardized residual values. After eliminating 47 outliers, the $p$-value for Kolmogorov-Smirnov test of normality was 0.20 , which exceeded 0.05 , thus satisfying the assumption of normality. This study presents the analysis using data collected from 243 participants, where the standardized beta and $p$-values are portrayed in Table 9.

The results revealed that the effects of participation years, total amount of economic loan received, and total number of center meetings/discussions attended on micro-enterprise sustainability appeared inconclusive (direction of the association and level of significance) for both groups ( $\mathrm{N}=300$ and $\mathrm{N}=243)$. The total number of training hours exhibited a positive effect on microenterprise sustainability, which had been significant only after discarding the outliers $(\mathrm{N}=243)$. The study outcomes, however, failed to give conclusive evidence about the impact of development programs participation on the sustainability of micro-enterprises owned and man-

Table 7. Regression Coefficients

\begin{tabular}{|c|c|c|c|c|c|c|c|}
\hline \multirow[t]{2}{*}{+2} & \multirow[t]{2}{*}{ Unst. Beta } & \multirow{2}{*}{$\begin{array}{l}\mathbf{N}=300 \\
\text { Std. Error }\end{array}$} & \multirow[t]{2}{*}{ Stan. Beta } & \multirow[t]{2}{*}{ Sig. } & \multirow[t]{2}{*}{ VIF } & \multicolumn{2}{|c|}{$\mathbf{N}=\mathbf{2 5 3}$} \\
\hline & & & & & & Stan. Beta & Sig. \\
\hline (Constant) & 3.458 & .208 & & .000 & & & .000 \\
\hline Years & .015 & .009 & .105 & .094 & 1.506 & .100 & .073 \\
\hline Loan & $-2.478 \mathrm{E}-007$ & .000 & -.013 & .852 & 1.819 & .084 & .153 \\
\hline Training & -.002 & .001 & -.078 & .166 & 1.208 & -.067 & .184 \\
\hline $\mathrm{MD}$ & -.123 & .031 & -.234 & .000 & 1.317 & -.268 & .000 \\
\hline Gender & -.209 & .068 & -.203 & .002 & 1.656 & -.126 & .032 \\
\hline Marital Status & .085 & .030 & .198 & .005 & 1.898 & .275 & .000 \\
\hline Age & .071 & .035 & .145 & .042 & 1.936 & -.061 & .355 \\
\hline Education & -.022 & .027 & -.051 & .421 & 1.526 & -.049 & .384 \\
\hline GEM & .004 & .064 & .004 & .952 & 1.967 & -.116 & .070 \\
\hline Sources of Income & -.061 & .069 & -.061 & .378 & 1.810 & -.069 & .251 \\
\hline Experience & .006 & .008 & .048 & .413 & 1.318 & .147 & .004 \\
\hline Established & .041 & .035 & .089 & .235 & 2.150 & .238 & .001 \\
\hline Full-Time Employees & -.141 & .049 & -.182 & .004 & 1.531 & -.401 & .000 \\
\hline Part-Time Employees & -.016 & .063 & -.015 & .802 & 1.318 & .212 & .000 \\
\hline Working Hours & .002 & .002 & .068 & .274 & 1.469 & .235 & .000 \\
\hline
\end{tabular}

Note: (Dependent variable) Micro-Enterprise Performance

(Independent variables) Years - Number of years; Loan - Total amount of economic loan received; Training - Total number of training hours; MD - Number of Centre Meetings or Discussions attended

(Control Variables) Gender, Marital Status, Age, Education, GEM - Gainfully Employed Members, Sources of Income, Experience - Prior Entrepreneurial Experience (Years), Established - Micro-Enterprise Established (Years), Number of FullTime Employees, Number of Part-Time Employees, Working Hours Per Week 
Table 8. Partial Correlation

\begin{tabular}{|c|c|c|c|c|c|c|}
\hline Variables & & MES & Year & Loan & Training & MD \\
\hline \multirow[t]{2}{*}{ Micro-Enterprise Performance } & Correlation & 1.000 & & & & \\
\hline & Sig. (1-tailed) & . & & & & \\
\hline \multirow[t]{2}{*}{ Number of years } & Correlation & .238 & 1.000 & & & \\
\hline & Sig. (1-tailed) & .000 & . & & & \\
\hline \multirow[t]{2}{*}{ Total amount of economic loan received } & Correlation & .070 & .057 & 1.000 & & \\
\hline & Sig. (1-tailed) & .118 & .167 & . & & \\
\hline \multirow[t]{2}{*}{ Total number of training hours } & Correlation & -.148 & -.112 & .266 & 1.000 & \\
\hline & Sig. (1-tailed) & .006 & .029 & .000 & . & \\
\hline \multirow[t]{2}{*}{ Number of Centre Meetings or Discussions attended } & Correlation & .126 & .035 & -.140 & -.274 & 1.000 \\
\hline & Sig. (1-tailed) & .016 & .279 & .009 & .000 & . \\
\hline
\end{tabular}

Note:

(a) MEP - Micro-Enterprise Performance; Years - Number of years; Loan - Total amount of economic loan received; Training - Total number of training hours; MD - Number of Centre Meetings or Discussions attended

(b) Control variables - gender, marital status, age, education, gainfully employed members, sources of income, prior entrepreneurial experience, micro-enterprise established, number of full-time employees, number of part-time employees, working hours per week.

Table 9. Regression Coefficients

\begin{tabular}{|c|c|c|c|c|c|c|c|}
\hline & \multirow[t]{2}{*}{ Unst. Beta } & \multirow{2}{*}{$\begin{array}{c}\mathrm{N}=\mathbf{3 0 0} \\
\text { Std. Error }\end{array}$} & \multirow[t]{2}{*}{ Stan. Beta } & \multirow[t]{2}{*}{ Sig. } & \multirow[t]{2}{*}{ VIF } & \multicolumn{2}{|c|}{$N=243$} \\
\hline & & & & & & Stan. Beta & Sig. \\
\hline (Constant) & 3.302 & .334 & & .000 & & & .000 \\
\hline Years & -.005 & .014 & -.024 & .706 & 1.506 & .010 & .876 \\
\hline Loan & $-3.614 \mathrm{E}-006$ & .000 & -.118 & .092 & 1.819 & -.156 & .022 \\
\hline Training & .002 & .002 & .051 & .371 & 1.208 & .173 & .002 \\
\hline $\mathrm{MD}$ & -.157 & .050 & -.189 & .002 & 1.317 & -.261 & .000 \\
\hline Gender & .113 & .109 & .069 & .301 & 1.656 & -.002 & .974 \\
\hline Marital Status & -.127 & .049 & -.187 & .009 & 1.898 & .004 & .959 \\
\hline Age & .220 & .056 & .283 & .000 & 1.936 & .235 & .001 \\
\hline Education & .058 & .043 & .086 & .180 & 1.526 & .064 & .323 \\
\hline GEM & -.205 & .103 & -.144 & .048 & 1.967 & -.040 & .580 \\
\hline Sources of Income & .008 & .110 & .005 & .940 & 1.810 & -.009 & .900 \\
\hline Experience & -.031 & .012 & -.152 & .011 & 1.318 & -.132 & .023 \\
\hline Established & .206 & .056 & .281 & .000 & 2.150 & .485 & .000 \\
\hline Full-Time Employees & .064 & .079 & .052 & .419 & 1.531 & .011 & .854 \\
\hline Part-Time Employees & -.293 & .102 & -.171 & .004 & 1.318 & -.247 & .000 \\
\hline Working Hours & .001 & .003 & .016 & .803 & 1.469 & -.105 & .083 \\
\hline
\end{tabular}

Note: (Dependent variable) Micro-Enterprise Performance

(Independent variables) Years - Number of years; Loan - Total amount of economic loan received; Training - Total number of training hours; MD - Number of Centre Meetings or Discussions attended

(Control Variables) Gender, Marital Status, Age, Education, GEM - Gainfully Employed Members, Sources of Income, Experience - Prior Entrepreneurial Experience (Years), Established - Micro-Enterprise Established (Years), Number of FullTime Employees, Number of Part-Time Employees, Working Hours Per Week 
aged by low-income households in Peninsular Malaysia (Hypothesis 3). Nonetheless, the analysis highlights the vital effect of micro-enterprise development training programs upon long-term sustainability of micro-enterprises owned and managed by low-income households in Peninsular Malaysia. As for the effects of control variables, the results revealed significantly positive impacts of entrepreneurs' age and micro-enterprises establishment on sustainability of micro-enterprises owned and managed by low-income households in Peninsular Malaysia. The effects of other control variables were mostly inconclusive (direction of the association and level of significance) for both groups ( $\mathrm{N}=300$ and $\mathrm{N}=243$ ).

\section{Discussion and Conclusion}

This study investigated the impact of micro-enterprise development initiatives on competitive advantages, performance, and sustainability of micro-enterprises owned and managed by low-income households in Peninsular Malaysia. As such, the study held onto the implication of two aspects; hypothetical and practical. As for the hypothetical aspect, a regression model of 300 samples had been assessed and the outcomes showed that the total amount of economic loan received, the total number of training hours, and the total number of center meetings/ discussions attended displayed significantly positive effects on competitive advantage for micro-enterprises owned and managed by low-income households in Peninsular Malaysia. Nevertheless, the duration of participation exerted insignificantly negative effect. As for the effect of control variables, the results revealed significantly positive impact of marital status on competitive advantages for micro-enterprises owned and managed by low-income households. The findings also revealed that the duration of participation and number of center meetings/discussions attended had a positive effect on microenterprise performance. However, the impacts of total amount of economic loan received and total number of training hours were inconclusive. The study outcomes failed to offer any clear evidence regarding the impact of development programs participation upon performance of micro-enterprises owned and managed by lowincome households in Peninsular Malaysia. Finally, the findings of this study failed in providing partial evidence for the impact of development programs participation on the sustainability of micro-enterprises owned and managed by low-income households in Peninsular Malaysia.
As for practical implication, this study shows that even though development agencies aim to enhance the socio-economic status among the low-income households in Malaysia, some effects of development initiatives are still inconclusive in terms of micro-enterprise competitive advantage, performance, and sustainability. These outcomes are, unfortunately, in line with the results reported by Angelucci et al. (2013) and Ganle et al. (2015). Armendáriz et al. (2005) asserted this variance by claiming that the impact of development initiatives differs from one context to another based on financial service providers, enterprise development, population density, group-cohesion, financial literacy, and attitudes to debt, to name a few. One possible explanation is that micro-enterprises are not directly affected by the development initiatives. Future researchers may further investigate the inconclusive findings of this study. In addition, a recent study conducted by Al-Mamun et al. (2018) proved that social capital and entrepreneurial competencies displayed significantly positive effects upon competitive advantage among women-owned and managed micro-enterprises. Therefore, future researchers should weigh in the mediating effects of social capital and entrepreneurial competencies between micro-enterprise development initiatives and sustainability. This inconclusiveness opens up more questions than answers, which require serious attention on why the effort of development agencies has failed in generating the intended results within the contexts of competitive advantage, performance, and sustainability of micro-enterprises owned and managed by low-income households in Peninsular Malaysia.

\section{References}

Abisuga-Oyekunle, O., \& Fillis, I. (2016). The role of handicraft micro-enterprises as a catalyst for youth employment. Creative Industries Journal, 10(1), 5974. https://doi.org/10.1080/17510694.2016.1247628

Adekunle, B. (2011). Determinants of microenterprise performance in Nigeria. International Small Business Journal, 29(4), 360-373. https://doi. org/10.1177/0266242610369751

Ahmed, F., Siwar, C., Bashawir, A., \& Mia, M. (2016). Urbanization and urban poverty in Malaysia: Consequences and vulnerability. Journal of Applied Sciences, 16(4), 154-160. https://doi.org/10.3923/ jas.2016.154.160

Akingunola, R. O., Olowofela, E. O., \& Yunusa, L. (2018). Impacts of microfinance bank on micro and small enterprise in Ogun State, Nigeria. Binus Business Review, 9(2), 163-169. https://doi.org/10.21512/ 
bbr.v9i2.4253

Al Mamun, A., Noorshella Binti Che, N., Permarupan, P., \& Muniady, R. (2018). Sources of competitive advantage for Malaysian micro-enterprises. Journal of Entrepreneurship in Emerging Economies 10(2), 191216. https://doi.org/10.1108/JEEE-05-2017-0037

Al-Mamun, A. (2014). Investigating the development and effects of social capital through participation in group-based microcredit programme in Peninsular Malaysia. Journal of Interdisciplinary Economics, 26(1-2), 33-59. https://doi. org/10.1177/0260107914540822

Al-Mamun, A., \& Mazumder, M. (2015). Impact of microcredit on income, poverty, and economic vulnerability in Peninsular Malaysia. Development in Practice, 25(3), 333-346. https://doi.org/10.1080/09 614524.2015.1019339

Al-Mamun, A., Abdul Wahab, S., \& Malarvizhi, C. (2010). Examining the effect of mMicrocredit on employment in Peninsular Malaysia. Journal of Sustainable Development, 4(2), 174-183. https://doi. org/10.2139/ssrn.1946093

Al-Mamun, A., Malarvizhi, C., Hossain, S., \& Wahab, S. (2011). Examining the effect of participation in microcredit programs on assets owned by hardcore poor households in Malaysia. African Journal of Business Management, 5(22), 9286-9296. https:// doi.org/10.5897/AJBM.9000273

Al-Mamun, A., Mazumder, M., \& Malarvizhi, C. (2014). Measuring the effect of Amanah Ikhtiar Malaysia's microcredit programme on economic vulnerability among hardcore poor households. Progress in Development Studies, 14(1), 49-59. https://doi. org/10.1177/1464993413504351

Al-Shami, S., Majid, I., Mohamad, M., \& Rashid, N. (2017). Household welfare and women empowerment through microcredit financing: Evidence from Malaysia microcredit. Journal of Human Behavior in The Social Environment, 27(8), 894-910. https://doi.org/10.1080/10911359.2017.1345341

Al-shami, S., Razali, R., \& Rashid, N. (2017). The Effect of Microcredit on Women Empowerment in Welfare and Decisions Making in Malaysia. Social Indicators Research, 137(3), 1073-1090. https://doi. org/10.1007/s11205-017-1632-2

Angelucci, M., Karlan, D., \& Zinman, J. (2013). Win some lose Some? Evidence from a randomized microcredit program placement experiment by Compartamos Banco (NBER Working Paper No. 19119). National Bureau of Economic Research. https://doi. org/10.3386/w19119

Armendáriz, Beatriz, Aghion, \& Jonathan, Morduch. (2005). The economics of microfinance. Economic Record, 82, 491-92. https://doi.org/10.1111/j.14754932.2006.00364.x

Atmadja, A., Su, J., \& Sharma, P. (2016). Examining the impact of microfinance on microenterprise performance (implications for women-owned microenterprises in Indonesia). International Journal of Social Economics, 43(10), 962-981. https://doi. org/10.1108/IJSE-08-2014-0158

Banerjee, A., Karlan, D., \& Zinman, J. (2015). Six randomized evaluations of microcredit: Introduction and further steps. American Economic Journal: Applied Economics, 7(1), 1-21. https://doi. org/10.1257/app.20140287

Barney, J. (1991). Firm resources and sustained competitive advantage. Journal of Management, 17(1), 99120. https://doi.org/10.1177/014920639101700108

Bikbaeva, G., \& Gaibnazarova, M. (2009). Impact of microfinance on alleviating rural poverty in Uzbekistan. Problems of Economic Transition, 52(2), 67-85. https://doi.org/10.2753/PET1061-1991520205

Chan, S., \& Abdul Ghani, M. (2011). The impact of microloans in vulnerable remote areas: evidence from Malaysia. Asia Pacific Business Review, 17(1), 45-66. https://doi.org/10.1080/13602380903495621

Clark, D. N. and Heather D. (2014). Micro-enterprise growth: Lessons from home-based business in New Zealand. Small Enterprise Research, 21, 82-98. https://doi.org/10.1080/13215906.2014.11082078

Danciu, V. (2013). The sustainable company: New challenges and strategies for more sustainability. Theoretical and Applied Economics, 20(9), 7-26

Deller, S., \& McConnon, J. (2009). Microenterprises and economic growth: A panel study of the US states 1977-1997. Applied Economics Letters, 16(13), 13071312. https://doi.org/10.1080/13504850701367361

Donou-Adonsou, F., \& Sylwester, K. (2016). Financial development and poverty reduction in developing countries: New evidence from banks and microfinance institutions. Review of Development Finance, 6(1), 82-90. https://doi.org/10.1016/j. rdf.2016.06.002

Economic Planning Unit (2002). Malaysian quality of life 2002. Prime Minister's Department.

Elliott, J. (2013). An introduction to sustainable development. Routledge.

Ferdousi, F. (2015). Impact of microfinance on sustainable entrepreneurship development. Development Studies Research, 2(1), 51-63. https://doi.org/10.10 80/21665095.2015.1058718

Fields, G. S. (2012). Poverty and low earnings in the developing world. In P. Jefferson (Ed.), The Oxford handbook of the economics of poverty (pp. 249276). Oxford University Press.

Gampala, P. (2018). Credit impact on performance of micro and small enterprises in Telangana. Academy of Entrepreneurship Journal, 24(1), 1-30

Ganle, J., Afriyie, K., \& Segbefia, A. (2015). Microcredit: Empowerment and disempowerment of rural women in Ghana. World Development, 66, 335-345. https://doi.org/10.1016/j.worlddev.2014.08.027

Gentry, W., \& Hubbard, R. (2004). Entrepreneurship and household saving. Advances in Economic Analysis \& Policy, 4(1), 1053-1053. https://doi.org/10.3386/ w7894

Halvarsson, D., Korpi, M., \& Wennberg, K. (2018). Entrepreneurship and income inequality. Journal of Economic Behavior \& Organization, 145, 275-293. https://doi.org/10.1016/j.jebo.2017.11.003

Hassan, M., \& Ibrahim, K. (2015). Sustaining small entrepreneurs through a microcredit program in Penang, Malaysia: A case study. Journal of Human 
Behavior in The Social Environment, 25(3), 182-191. https://doi.org/10.1080/10911359.2014.956961

Heltberg, R., Oviedo, A. M., \& Talukdar, F. (2015). What do household surveys really tell us about risk, shocks, and risk management in the developing world? Journal of Development Studies, 51, 209-225. https://doi.org/10.1080/00220388.2014.959934

Islam, D., Sayeed, J., \& Hossain, N. (2016). On determinants of poverty and inequality in Bangladesh. Journal of Poverty, 21(4), 352-371. https://doi.org/10.10 $80 / 10875549.2016 .1204646$

Kotler, Philip. (2000). Marketing management. PrenticeHall.

Kuo, S., Lin, P., \& Lu, C. (2017). The effects of dynamic capabilities, service capabilities, competitive advantage, and organizational performance in container shipping. Transportation Research Part A: Policy and Practice, 95, 356-371. https://doi.org/10.1016/j. tra.2016.11.015

Ma, H. (2000). Competitive advantage and firm performance. Competitiveness Review, 10(2), 15-32. https://doi.org/10.1108/eb046396

Mahmood, R., \& Mohd Rosli, M. (2013). Microcredit position in micro and small enterprise performance: the Malaysian case. Management Research Review, 36(5), 436-453. https://doi. org/10.1108/01409171311327226

Mann, S., and Gazzarin C. (2004). Sustainability indicators for Swiss dairy farms and the general implications for business/government interdependencies. International Review of Administrative Sciences, 70, 111-121. https://doi. org/10.1177/0020852304041234

Molnár, G. (2017). Capability building combined with microcredit: The loan alone is insufficient. Journal of Social Entrepreneurship, 8(3), 354-374. https:// doi.org/10.1080/19420676.2017.1371632

Montgomery, H., \& Weiss, J. (2011). Can commerciallyoriented microfinance help meet the Millennium Development goals? Evidence from Pakistan. World Development, 39, 87-109. https://doi.org/10.1016/j. worlddev.2010.09.001

Muniady, R., Mamun, A., Mohamad, M., Permarupan, P., \& Zainol, N. (2015). The effect of cognitive and relational social capital on structural social capital and micro-enterprise performance. SAGE Open, 5(4), 1-9. https://doi.org/10.1177/2158244015611187

Mustapa, W. N. W., Al-Mamun, A., \& Ibrahim, M. D. (2018). Development initiatives, microenterprise performance and sustainability. International Journal of Financial Studies, 6(3), 1-15. https://doi. org $/ 10.3390 /$ ijfs6030074

Nair, S. (2010, September). Moving forward: Its poverty agenda challenges, dilemmas and options for Malaysia. In Proceedings of the Chronic Poverty Research Centre 2010 Conference (pp. 8-10).

Nair, S., \& Sagaran, S. (2015). Poverty in Malaysia: Need for a paradigm shift. Institutions and Economies, 7(3), 95-123.

Norshafizah, H. (2012). Business performance of womenowned SMEs in Malaysia: Learning and entrepre- neurial orientations and the mediating roles of competitive advantage [Doctoral dissertation, Universiti Utara Malaysia]. Sintok, Malaysia. http://etd.uum. edu.my/3777/

Ocampo, L. A., Vergara, V. G., Impas, C., Tordillo, J. A., \& Pastoril, J. (2015). Identifying critical indicators in sustainable manufacturing using analytic hierarchy process (AHP). Journal of Manufacturing and Industrial Engineering, 14(3-4), 1-8.

Porter, M. E. (1996). What is strategy? Harvard Business Review, 74(6), 61-78.

Samer, S., Majid, I., Rizal, S., Muhamad, M. R., \& Rashid, N. (2015). The impact of microfinance on poverty reduction: Empirical evidence from Malaysian perspective. Procedia-Social and Behavioral Sciences, 195, 721-728. 